\title{
Antimicrobial Activity of Purified Toxins from Crossopriza lyoni (Spider) against Certain Bacteria and Fungi
}

\author{
Ravi Kumar Gupta, Ravi Kant Upadhyay \\ Department of Zoology, DDU Gorakhpur University, Gorakhpur, India \\ Email: rkupadhya@yahoo.com
}

Received 30 May 2016; accepted 22 July 2016; published 25 July 2016

Copyright (C) 2016 by authors and Scientific Research Publishing Inc.

This work is licensed under the Creative Commons Attribution International License (CC BY). http://creativecommons.org/licenses/by/4.0/

\section{Open Access}

\section{Abstract}

Toxins from spider venom Crossopriza lyoni were subjected to purify on a Sepharose CL-6B 200 column. These were investigated for its antibacterial and antifungal activity against 13 infectious microbial pathogenic strains. Antimicrobial susceptibility was determined by using paper disc diffusion and serial micro-dilution assays. Triton $\mathrm{X}-100(0.1 \%)$ proved to be a good solubilizing agent for toxin/proteins. Higher protein solubilization was observed in the supernatant than in the residue, except TCA. The elution pattern of purified and homogenized sting poison glands displayed two major peaks at $280 \mathrm{~nm}$. First one was eluted in fraction No. 43 - 51 while second one after fraction no. 61 - 90. From gel filtration chromatography total yield of protein obtained was $67.3 \%$. From comparison of gel chromatographs eluted toxins peptide molecular weight was ranging from 6.2 - $64 \mathrm{kD}$. Toxin peptides have shown lower MIC values i.e. 7.5 - $15 \mu \mathrm{g} / \mathrm{ml}$ against $K$. pneumoniae, E. coli, L. acidophilus, B. cereus; against $S$. aureus and $M$. luteus that the broad spectrum antibiotics i.e. tetracycline and ampicillin. In tests, larger inhibition zone diameter was obtained in comparison to control. Diameter of inhibition zones obtained in spider toxins at a concentration range of 197.12 - 0.96 $\mu \mathrm{g} / \mathrm{ml}$ for E. coli was $17.86 \pm 0.21$, Bacillus cereus $19.13 \pm 0.21$, L. acidophilus $16.83 \pm 0.25$, Micrococcus luteus $18.46 \pm 0.17$, S. aeurus $16.23 \pm 0.19$, Klebsiella pneumoniae $21.83 \pm 0.16$, Salmonella typhi $16.16 \pm 0.21$, Vibrio cholerae 18.66 \pm 0.21 , Pseudomonas aeruginosa $18.66 \pm 0.21$, Aspergillus niger $22.9 \pm 0.24$, Candida albicans $24.66 \pm 0.28$, Rhizopus stolonifer $21.1 \pm 0.16$. Spider toxins generate cytotoxic effect on bacterial cells that results in heavy cell death. No doubt spider toxins can be used as alternate of broad spectrum antibiotics.

\section{Keywords}

Spider Toxins, Voltage Gates, Antibacterial, Antifungal, Susceptibility, Antimicrobials, Bio-Insecticides 


\section{Introduction}

Envenomation in spiders is an adaptive evolutionary mechanism that is used to protect the territory and to obtain food. Spider bites are a major problem in many Asian, African and other tropical countries. Spiders hide in crevices to predate or hunt insects. They make a web of thread to catch the insects or sting it to paralyze simultaneously. Spiders are arachnids which bear toxins in their mouth and belong to family Arenae. During long evolutionary timescale, spiders have evolved complex venoms that are employed to subdue prey and deter predator [1]. Spider toxins are short basic peptides of 32 - 76 amino acids in length. These are highly toxic in nature. Only exception is Latrotoxin which possess 1401 amino acids with 4 disulphide bridges. Spider toxins show diverse biological effects in animals i.e. scratching, lacrimation, hypertension, salivation, sweating, agitation followed by spastic paralysis of the posterior and anterior extremities. Spider toxins show diverse biological effects in animals such as muscle and respiratory paralysis, integumentary, neuro-inflammatory and neuro-pathological effects in prey. Spider toxins (JZ TX-V) inhibit ion channels present on nerve cell membrane [2] and show platelet aggregation in haemostatic system [3]. These toxins are either acylpolyamine or polypeptides which cause irreversible paralysis in lepidopteran insects by massive transmitter release. Spider toxins also generate insecticidal effect and kill insect larvae at a very low dose $0.05 \mathrm{mg} / \mathrm{gm}$ body weight.

Spider venom toxin peptides interact with ligand gated channels and modulate the activity of neuronal ion channels and receptors. These target voltage gated potassium (Kv), calcium (Cav) or sodium (Nav) channels. Spider-venom peptides target vertebrate or invertebrate $\mathrm{Na}(\mathrm{V})$ channels. They also target specific $\mathrm{Na}(\mathrm{V})$ channel subtypes that are considered to be important analgesic targets. Spider venom peptides bind on purinergic receptors, channels such as acid sensing ion channels, mechanosensitive channels and transient receptors and potassium channels. Spider venom toxins show action agents against more than 65 blockers of vertebrates Cav channels and which of them found are active mainly on Cav 2.2. Venom composition is highly species specific and depends on many climatic and biological factors. Spider venom contains a mixture of biologically active compounds with different biochemical activities. These compounds are enzymes, proteins, polyamines and acids which show multiple biological effects in animals as well as in human. Spider venom toxins generate necrotizing skin lesions, cell necrosis, and show systemic reactions and impose death in animals [4]. Venom toxins show analgesic effect, do inhibition of voltage gated ion channels [5] and generate various channelopathies including epilepsy, arrhythmia, and paralytic myotonic effect with severe pain [2]. Toxin peptides can also become a good source of strong antimicrobials and can replace broad spectrum antibiotics which are highly toxic and show multiple biological effects and responsible for drug resistance in microbes [6]. Spider venom is concerned to be a potential source of modulators for all of drug targets. These are proved much valuable tool for the investigation of structure and function of channels and for drug development [7]. Molecular templates of spider toxins and using recent technologies spider toxins can be used for production of good therapeutic agents mainly antimicrobials, anticancer agents and bio-insecticides. Spider venom includes substances of different chemical nature which possess immense therapeutic potential against a wide range of pathophysiological conditions including cardiovascular disorders, chronic pain, inflammation and erectile dysfunction. Spider venoms contain a plethora of insecticidal peptides that act on neuronal ion channels and receptors. Because of their high specificity, potency and stability, these peptides have attracted much attention as potential environmentally friendly insecticides. Although many insecticidal spider venom peptides have been isolated, the molecular target, mode of action and structure of only a small minority have been explored. Present study deals with isolation, purification and characterization of spider venom toxins and generation of polyclonal antibodies and its protective effect in mice model and their antimicrobial susceptibility to certain bacteria and fungi.

\section{Material and Method}

\subsection{Microbial Culture}

Escherichia coli (ATCC 25,922), Bacillus cereus (ATCC 11,778), Lactobacillus acidophilus (ATCC 53,103), Micrococcus luteus (ATCC 9341), Staphylococcus aureus (ATCC 25,923), Klebsiella pneumoniae (ATCC 15,380) and Streptococcus pneumoniae (ATCC 12,755), Salmonella typhi (MTCC 98), Vibrio cholera (MTCC 3906), Pseudomonas aeruginosa (MTCC 4996), Aspergillus niger (MTCC 1344), Candida albicans (MTCC 227), Rhizopus stolonifer (MTCC 2456) were maintained in the laboratory in Luria Broth (2\% w/v) for four days at $37^{\circ} \mathrm{C}$ before use, $100 \mu \mathrm{l}$ of the overnight culture was mixed in the tests and control. Bacterial cultures were stored at $4^{\circ} \mathrm{C}$ and sub cultured after every $8^{\text {th }}$ day in solid agar plates. 


\subsection{Purification of Spider Venom}

The Spider Crossopriza lyoni were collected from different region of Gorakhpur. They were immobilized by quick freezing at -20 degree centigrade. The venom reservoir i.e., venom poison glands were taken out by mouth part (Chelicerae) and homogenized in phosphate buffer saline (50 mM, pH 7.2) with the help of power homogenizer. The homogenate spider toxins centrifuged at $3000 \mathrm{~g}$ at $4{ }^{\circ} \mathrm{C}$ for 5 minutes and the supernatant was used as crude venom.

Field collected Spider Crossopriza lyoni 300 in number were anesthetized with chloroform, dissected in cold PBS (pH 6.9) and their poison gland with chelicerae and their sting apparatus with glands venom gland of were taken out from its last segment. These were homogenized in a glass homogenizer in $5 \mathrm{ml}$ of different solubilizing buffer viz. Triton X-100, Phosphate buffer (50 mM, pH 7.2), 10\% TCA (Trichloroacetic acid), EDTA + Tris [Hydroxy methyl Methyl amino] and Ethanol separately. Homogenate was centrifuged at $10,000 \mathrm{~g}$ at $4^{\circ} \mathrm{C}$ for 5 minutes and supernatant was taken out and Venom protein present in the supernatant was estimated according the method of Lowry's method [8]. Besides this, proteins (tissue) were solubilized in other solubilizing agents (Triton X 100, PBS, 10\% TCA, and EDTA + Tris) in different combinations. Homogenate was centrifuged at 12,000 rpm for 30 min and proteins were estimated in supernatant according to Lowry's method [8].

\subsection{Solubilization of Venom Gland Homogenate}

Proteins were eluted on a Sepharose CL-6B 200 a double cavity gel filtration column [9] with sintered disc fitted in the bottom having a height of 1 meter in $25 \mathrm{~mm}$ diameter. A known volume of toxins/proteins solubilized in PBS (pH 6.8), was loaded in the column and a flow rate between $20-24 \mathrm{ml} / \mathrm{hr}$ was maintained by a continuous buffer supply in a cold room. Eluted fractions were collected at a fixed time interval using a Pharmacia fraction collector and the values of protein concentration in different eluted fractions were plotted on graph; absorbance was determined at $280 \mathrm{~nm}$. Column was tightly held by clips and held erect with a stand. The eluted fractions containing venom proteins were pooled and lyophilized to a desired concentration of venom proteins. Dialysis bag made of cellulose membrane was boiled for 10 minutes in a large volume of $2 \%(\mathrm{w} / \mathrm{v})$ sodium bicarbonate and 1mM EDTA ( $\mathrm{pH}$ 8.0) and then rinsed the membrane thoroughly in distilled water. The membrane was then cooled and stored at $4{ }^{\circ} \mathrm{C}$. Membrane was washed with distilled water inside and outside before use. The lyophilized venom protein was filled in the dialyzing bag and dialyzed again three changes of phosphate buffer (50 $\mathrm{mM}, \mathrm{pH}$ 7.2) to remove the excess salt from the lyophilized protein venom solution of Spider Crossopriza lyoni.

\subsection{Antimicrobial Assays}

Spider Crossopriza lyoni venom toxin was evaluated for antibacterial activity by agar disc diffusion method. Six mm sterile filter paper discs (Whatman No. 1) were coated with four different concentrations of Spider toxin, prepared in phosphate buffer saline (pH 6.9). Inoculum size was adjusted to $10^{6}$ colony-forming units (CFU/ml). It was spread evenly on agar plate surface by a sterile rubber pad. Each toxin was assayed in triplicate. Sterile distilled water was used as negative control. Tetracycline, ampicillin and ciprofloxacin were used for comparison. Plates were incubated for $24 \mathrm{~h}$ at $37^{\circ} \mathrm{C}$ and diameter of inhibition zones were measured [10].

Susceptibility tests in liquid medium were conducted according to Amsterdam [11]. Spider toxin was diluted by serial micro dilution method (up to $10^{-10}$ ) using Luria Broth, final concentrations ranged from 58.57 to 0.229 $\mathrm{mg} / \mathrm{ml}$ and assays were done in triplicate. MIC values were the lowest concentration of spider toxins where no turbidity was observed in the culture flask after 24 hours incubation at $37^{\circ} \mathrm{C}$ and it was standardized in terms of absorbance at $600 \mathrm{~nm}$ in a spectrophotometer. For the determination of minimum bacterial concentration (MBC) inoculum size was adjusted to $10^{6} \mathrm{CFU} / \mathrm{ml}$ in sterile agar plates and determined again after incubation at $37^{\circ} \mathrm{C}$ for $24 \mathrm{~h}$ in all test and control discs. The lowest concentration at which no visible growth was obtained in agar plates was considered as MBC value. For evaluation of inhibition two parallel controls were set for each test extract. Bacterial growth was observed in presence of different quantities of spider venom toxin as well as in its absence.

\section{Results}

Before antimicrobial susceptibility testing, proteins were solubilized in different solubilizing buffers. Triton X$100(0.1 \%)$ proved to be a good solubilizing agent for toxin/proteins. Higher protein solubilization was observed 
in the supernatant than in the residue, except TCA (Figure 1). Gel filtration elution pattern displayed two major peaks at $280 \mathrm{~nm}$ in fraction no. 43 - 51 and 61 - 90 (Figure 2(a)). Further, estimation of venom proteins in above fractions was determined by Further Lowry's method (1951). Again two similar peaks were resolved at the same place, a minor one was obtained between fractions 43 - 51 and a major peak between fractions 61 - 90 (Figure 2(b)). Both peaks were eluted with PBS buffer (pH 6.9) (Figure 2(c)). The total yield of protein was $67.3 \%$ and specific activity was determined in each fraction (Figure 2(d)). Molecular weights in protein fractions were ranging from $6.2-70 \mathrm{kD}$ (Figure 2(e)).

MIC values were $7.5 \mu \mathrm{g} / \mathrm{ml}$ against K. pneumoniae $7.5 \mu \mathrm{g} / \mathrm{ml}$ against E. coli and L. acidophilus, $15.00 \mu \mathrm{g} / \mathrm{ml}$ against $B$. cereus; $15.00 \mu \mathrm{g} / \mathrm{ml}$ against $S$. aureus and $M$. luteus. The results suggest that $E$. coli and $B$. cereus were most susceptible to spider toxins while $K$. pneumoniae was least susceptible. MIC values for tetracycline and ampicillin were $27.5 \mu \mathrm{g} / \mathrm{ml}$ and for ciprofloxin $25 \mu \mathrm{g} / \mathrm{ml}$ against K. pneumoniae. (Table 1). Salmonella typhi $3.75 \mu \mathrm{g} / \mathrm{ml}$, Vibrio cholerae $3.75 \mu \mathrm{g} / \mathrm{ml}$, Pseudomonas aeruginosa $15.0 \mu \mathrm{g} / \mathrm{ml}$ respectively, while MIC value obtained against fungal strains i.e. Aspergillus niger $7.5 \mu \mathrm{g} / \mathrm{ml}$, Candida albicans $7.5 \mu \mathrm{g} / \mathrm{ml}$, Rhizopus stolonifer $3.75 \mu \mathrm{g} / \mathrm{ml}$ (Table 1$)$.

By agar disc diffusion method the diameter of inhibition zones in $\mathrm{mm}$ in presence of Spider toxins at a concentration range of $197.12-0.96 \mu \mathrm{g} / \mathrm{ml}$ E. coli $17.86 \pm 0.21$, Bacillus cereus $19.13 \pm 0.21$, L. acidophilus $16.83 \pm$ 0.25 , Micrococcus luteus $18.46 \pm 0.17$, S. aeurus $16.23 \pm 0.19$, Klebsiella pneumoniae $21.83 \pm 0.16$, Salmonella typhi $16.16 \pm 0.21$, Vibrio cholerae $18.66 \pm 0.21$, Pseudomonas aeruginosa $18.66 \pm 0.21$, Aspergillus niger $22.9 \pm$ 0.24 , Candida albicans $24.66 \pm 0.28$, Rhizopus stolonifer $21.1 \pm 0.16$ (Table 2).

\section{Discussion}

In the present study, antimicrobial activity of purified spider toxins was determined in vitro and compared with broad-spectrum antibiotics. From antimicrobial susceptibility tests, it was found that antibiotics were found less active than the spider venom toxins against the test bacteria and fungi. From the antimicrobial bioassays significantly lower MIC values were observed in spider toxins than the broad spectrum antibiotics. MIC values determined were $7.5 \mu \mathrm{g} / \mathrm{ml}$ against $K$. pneumonia, and E. coli and $15 \mu \mathrm{g} / \mathrm{ml}$ against L. acidophilus, $15 \mu \mathrm{g} / \mathrm{ml}$ against B. cereus; $3.75 \mu \mathrm{g} / \mathrm{ml}$ against S. aureus and 7.5 against $\mu \mathrm{g} / \mathrm{ml}$ M. luteus. Both E. coli, S. aeurus, and L. acidophilus were found most susceptible to spider toxins while Aspergillus niger was least susceptible. MIC values for tetracycline were $12.5 \mu \mathrm{g} / \mathrm{ml}$ and ampicillin were $13.75 \mu \mathrm{g} / \mathrm{ml}$ and for ciprofloxin $25 \mu \mathrm{g} / \mathrm{ml}$ against $K$. pneumoniae (Table 1). Salmonella typhi and Vibrio cholerae $24.69 \mu \mathrm{g} / \mathrm{ml}$, Pseudomonas aeruginosa $15 \mu \mathrm{g} / \mathrm{ml}$

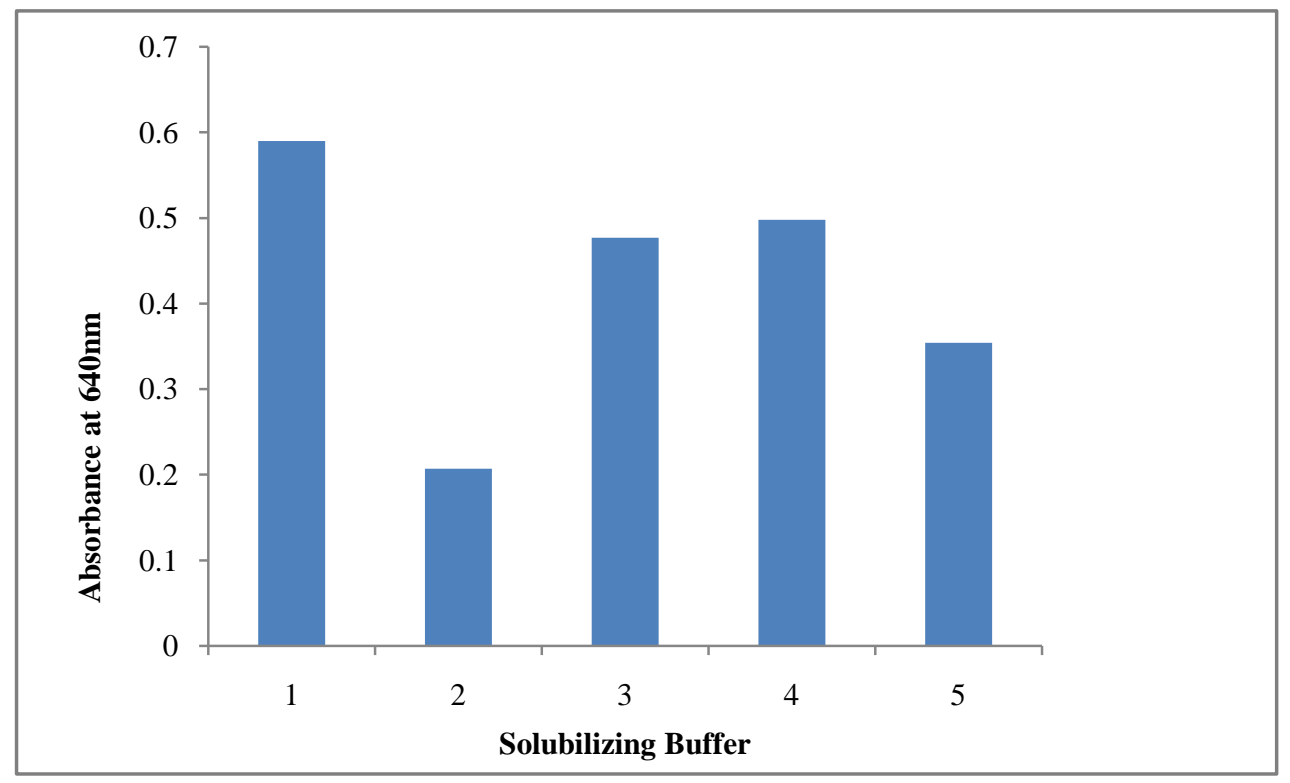

Figure 1. Solubilization of venom sting poison gland proteins of Spider Crossopriza lyoni different buffers. Absorbance of solubilized protein was taken at $640 \mathrm{~nm}$. 1. Triton X-100, 2. Phosphate buffer, 3. 10\% TCA, 4. EDTA + Tris, 5. Absolute Ethanol. 


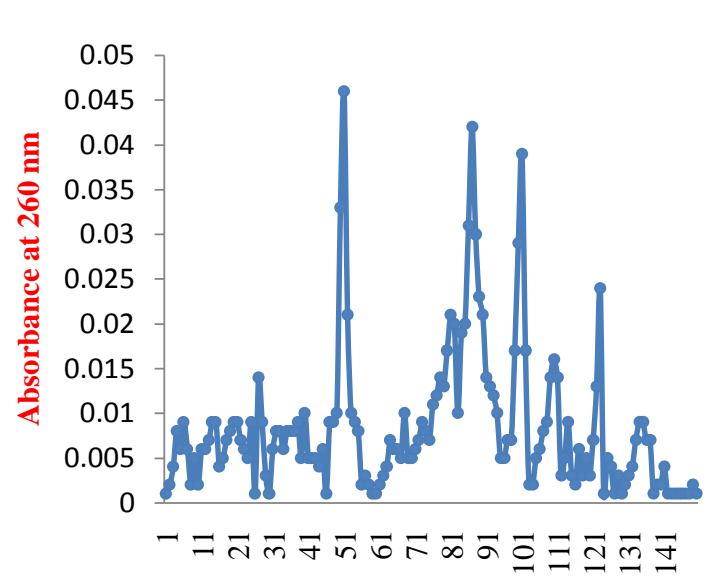

Fraction number

(a)

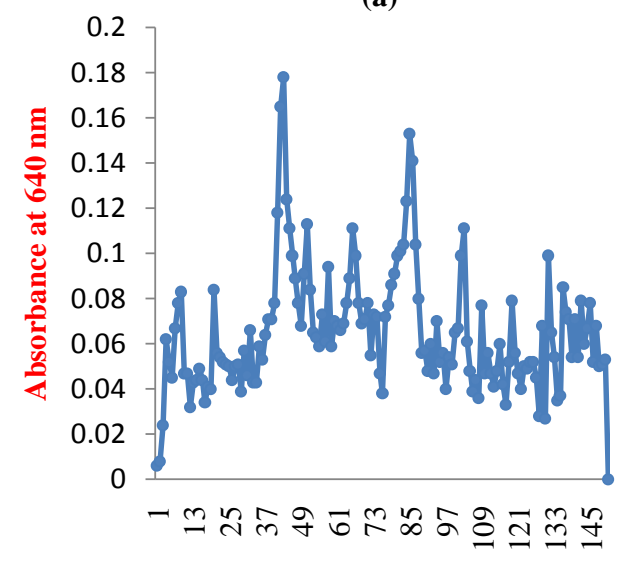

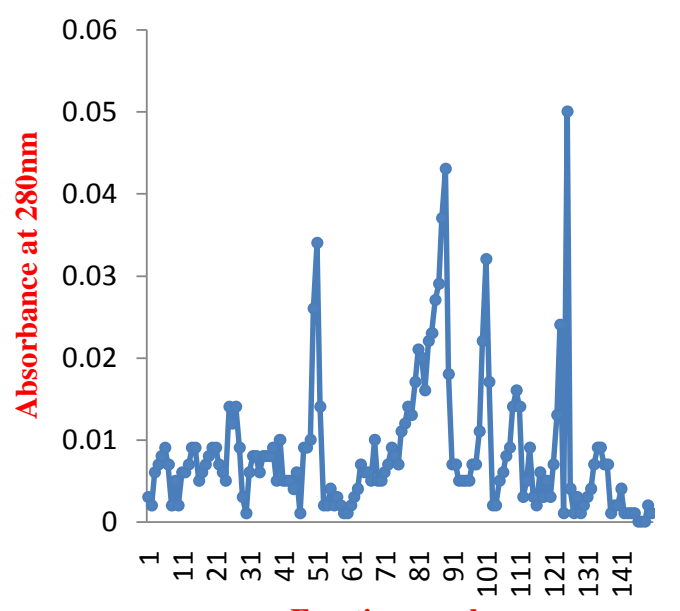

Fraction number

(b)

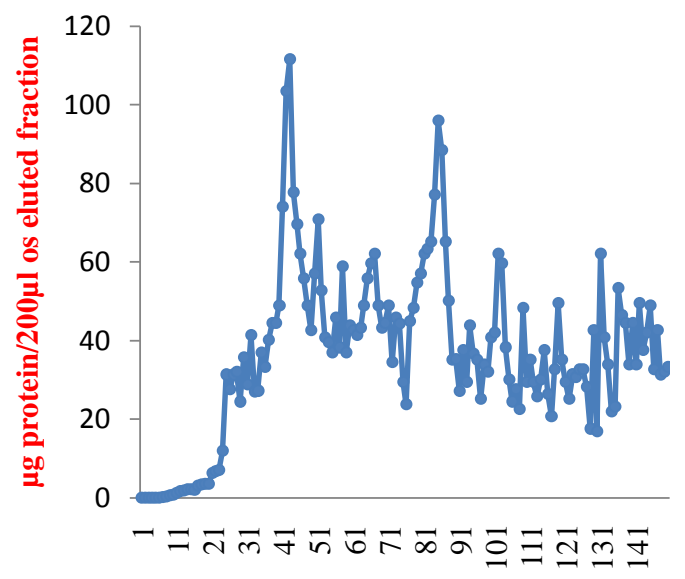

Fraction number

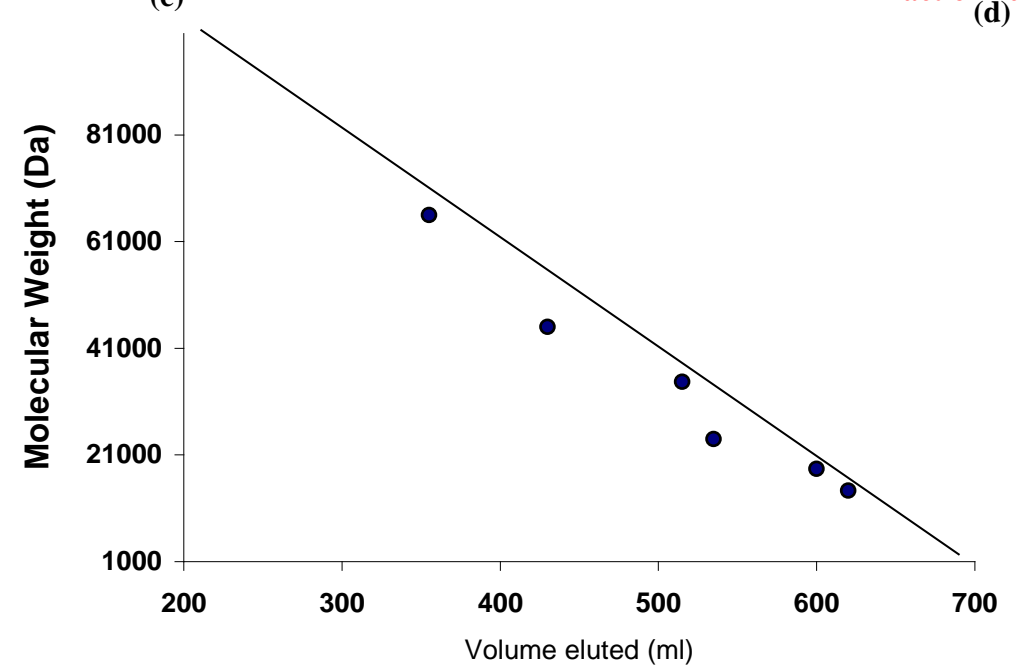

(e)

Figure 2. Elution pattern of PBS extractable proteins of Crossopriza lyoni chromatographed on Sepharose CL-6B column (a) absorbance at $260 \mathrm{~nm}$., (b) absorbance at $280 \mathrm{~nm}$., (c) absorbance at 640, (d) $\mu$ g protein/ $200 \mu$ fraction, and, (e) Standard proteins chromatographed on Sepharose standard CL-6B 200 column for determining the molecular weights of venom proteins/ peptides isolated from Crossopriza lyoni. Proteins used were bovine albumin mol. Wt. 66,000, egg albumin mol. wt. 45,000, pepsin mol. wt. 34,700, trypsinogen mol. wt. 24,000, beta lactoglobulin mol. wt 18,400 and lysozyme mol. wt. 14,300. Elution volumes of unknown proteins were compared with log values on the X-axis for estimation of molecular weights. 
Table 1. Antimicrobial activities of venom poison gland toxins isolated from Spider Crossopriza lyoni on different microbes and their corresponding minimum inhibitory concentration MIC.

\begin{tabular}{|c|c|c|c|c|c|c|c|}
\hline \multirow{3}{*}{ S.N. } & \multirow{3}{*}{ Name of organism } & \multirow{3}{*}{$\begin{array}{l}\text { Toxin conc. range } \\
\text { used }(\mu \mathrm{g} / \mathrm{mL})\end{array}$} & \multirow{3}{*}{$\begin{array}{c}\text { Toxin MIC } \\
\text { Test }\end{array}$} & \multicolumn{4}{|c|}{ Antibiotics MIC } \\
\hline & & & & \multicolumn{4}{|c|}{ Controls } \\
\hline & & & & Negative & Positive 1 & Positive 2 & Positive 3 \\
\hline 1 & E. coli & $60-0.127$ & 7.5 & - & 12.5 & 27.5 & 25 \\
\hline 2 & Bacillus cereus & $120-0.127$ & 15 & - & 25 & 27.5 & 25 \\
\hline 3 & L. acidophilus & $120-0.127$ & 15 & - & 25 & 27.5 & 25 \\
\hline 4 & Micrococcus luteus & $60-0.127$ & 7.5 & - & 12.5 & 55 & 12.5 \\
\hline 5 & S. aeurus & $60-0.234$ & 3.75 & - & 12.5 & 27.5 & 12.5 \\
\hline 6. & Streptococcus pneumonia & $60-0.234$ & 3.75 & & 6.75 & 13.75 & 12.5 \\
\hline 7 & Klebsiella pneumonia & $60-0.234$ & 7.5 & - & 12.5 & 13.75 & 25 \\
\hline 8 & Salmonella typhi & $60-0.234$ & 3.75 & - & 6.75 & 6.87 & 12.5 \\
\hline 9 & Vibrio cholera & $60-0.234$ & 3.75 & - & 6.75 & 6.87 & 12.5 \\
\hline 10 & Pseudomonas aeruginosa & $60-0.127$ & 15 & & 50 & 55 & 25 \\
\hline 11 & Aspergillus niger & $120-0.127$ & 7.5 & - & Gf 55 & Gf & Gf \\
\hline 12 & Candida albicans & $120-0.127$ & 7.5 & - & Gf 27.5 & Gf & Gf \\
\hline 13 & Rhizopus stolonifer & $120-0.127$ & 3.75 & - & Gf 13.75 & Gf & Gf \\
\hline
\end{tabular}

Positive controls are 1. tetracycline, 2. ampicillin \& 3. ciprofloxacin and Tests represents spider toxins, "-” negative control is DMSO, Gsf Griseofulvin, $\mathrm{ND}=$ not done.

Table 2. Zone of inhibition of spider venom toxin poison gland isolated Spider Crossopriza lyoni from on different microbes and their corresponding IZD.

\begin{tabular}{|c|c|c|c|c|c|c|c|}
\hline \multirow{3}{*}{ S.N. } & \multirow{3}{*}{$\begin{array}{c}\text { Name of } \\
\text { organism }\end{array}$} & \multirow{3}{*}{$\begin{array}{c}\text { Toxin conc. range } \\
\text { used }(\mu \mathrm{g} / \mathrm{mL})\end{array}$} & \multirow{3}{*}{$\begin{array}{c}\text { Spider toxin IZD } \\
\text { (mm) }\end{array}$} & \multicolumn{4}{|c|}{ Antibiotics MIC } \\
\hline & & & & \multicolumn{4}{|c|}{ Controls } \\
\hline & & & & Negative & Positive 1 & Positive 2 & Positive 3 \\
\hline 1 & E. coli & $98.56-0.192$ & $17.86 \pm 0.21$ & - & $13.8 \pm 0.12$ & $16.43 \pm 0.28$ & $9.86 \pm 0.17$ \\
\hline 2 & Bacillus cereus & $49.24-0.096$ & $19.13 \pm 0.21$ & - & $11.8 \pm 0.16$ & $12.30 \pm 0.18$ & $9.33 \pm 0.15$ \\
\hline 3 & L. acidophilus & $98.56-0.192$ & $16.83 \pm 0.25$ & - & $13.16 \pm 0.11$ & $10.30 \pm 0.21$ & $12.83 \pm 0.2$ \\
\hline 4 & Micrococcus luteus & $49.24-0.192$ & $18.46 \pm 0.17$ & - & $17.66 \pm 0.24$ & $10.23 \pm 0.19$ & $14.13 \pm 0.19$ \\
\hline 5 & S. aeurus & $49.24-0.096$ & $16.23 \pm 0.19$ & - & $13.73 \pm 0.22$ & $10.63 \pm 0.25$ & $11.16 \pm 0.21$ \\
\hline 6. & $\begin{array}{l}\text { Streptococcus } \\
\text { pneumoniae }\end{array}$ & $49.24-0.096$ & $18.43 \pm 0.26$ & - & $11.3 \pm 0.18$ & $9.1 \pm 0.32$ & $12.03 \pm 0.34$ \\
\hline 7 & $\begin{array}{l}\text { Klebsiella } \\
\text { pneumonia }\end{array}$ & $98.56-0.192$ & $21.83 \pm 0.16$ & - & $12.3 \pm 0.19$ & $14.23 \pm 0.21$ & $9.80 \pm 0.18$ \\
\hline 8 & Salmonella typhi & $98.56-0.192$ & $16.16 \pm 0.21$ & - & $11.3 \pm 0.25$ & $13.60 \pm 0.23$ & $12.00 \pm 0.24$ \\
\hline 9 & Vibrio cholera & $98.56-0.192$ & $18.66 \pm 0.21$ & - & $11.03 \pm 0.17$ & $12.36 \pm 0.28$ & $13.60 \pm 0.23$ \\
\hline 10 & $\begin{array}{c}\text { Pseudomonas } \\
\text { aeruginosa }\end{array}$ & $98.56-0.192$ & $18.66 \pm 0.21$ & - & $12.8 \pm 0.19$ & $12.76 \pm 0.15$ & $14.66 \pm 0.28$ \\
\hline 11 & Aspergillus niger & $197.12-0.385$ & $22.9 \pm 0.24$ & - & $11.3 \pm 0.19$ & ND & ND \\
\hline 12 & Candida albicans & $98.56-0.192$ & $24.66 \pm 0.28$ & & $12.4 \pm 0.9$ & ND & ND \\
\hline 13 & Rhizopus stolonifer & $49.24-0.192$ & $21.1 \pm 0.16$ & & $13.8 \pm 0.18$ & ND & ND \\
\hline
\end{tabular}

Values are expressed as mean $\pm \mathrm{SD}(N=3)$ and values followed by same letter are not significantly different at the $\mathrm{p}<0.05$ determined by Duncan's Multiple Range Test. Negative control is DMSO, Positive control are 1. tetracycline, 2. ampicillin \& 3. ciprofloxacin and T represents spider toxins. IZD = inhibition zone diameters. 
respectively, while MIC value obtained against fungal strains i.e. Aspergillus niger and Candida albicans 7.5 $\mu \mathrm{g} / \mathrm{ml}$, Rhizopus stolonifer $3.75 \mu \mathrm{g} / \mathrm{ml}$ (Table 1). Similar activity was reported in the spider venom peptide Lycosin-II against clinically isolated bacterial pathogens [12] and Latarcins, the versatile spider venom peptides [13]. Spider venom possesses proteinaceous toxins which show remarkable insecticidal and antibacterial activities [14]. Lycosin-I as a shows much higher antipathogenic action in vitro and is used as an alternative antimicrobial drug for treatment of multidrug-resistant Acinetobacter baumannii infections [12] [15], notably, expression of a spider toxin in tobacco inhibits the growth of microbes and insects [16]. Lycosin-I, as is a cationic and amphiphilic peptide isolated from the venom of the spider Lycosa singorensis [17] strongly act upon lipid membrane, lyses it and obstructs its integrity. Spider toxins also showed gating modifier action that works on mechanosensitive channels according to membrane thickness [18]. Antimicrobial peptides from arachnid venoms showed better microbicidal activity in the presence of commercial antibiotic due to additive effect on membrane lysis [19]. A single glycine to alanine substitution in antimicrobial peptide latarcin 2a increases interactions with lipid membrane [20]. Similarly, L- to D-amino acid substitution affects deamidation activity and membrane interactions [21]. From the inhibition zone diameter assays the IZDs obtained were larger in case of spider venom than antibiotics Similar action of spider toxins was observed in agar disc diffusion bioassay in which diameter of inhibition zones was E. coli $17.86 \pm 0.21$, Bacillus cereus $19.13 \pm 0.21$, L. acidophilus $16.83 \pm 0.25$, Micrococcus luteus $18.46 \pm 0.17$, S. aeurus $16.23 \pm 0.19$, Klebsiella pneuminiae $21.83 \pm 0.16$, Salmonella typhi $16.16 \pm$ 0.21 , Vibrio cholerae $18.66 \pm 0.21$, Pseudomonas aeruginosa $18.66 \pm 0.21$, Aspergillus niger $22.9 \pm 0.24$, Candida albicans $24.66 \pm 0.28$, Rhizopus stolonifer $21.1 \pm 0.16$ (Table 2). Inhibition zone diameters in $\mathrm{mm}$ for tetracycline, ampicillin and ciprofloxacin against S. aureus, K. pneumoniae, E. coli, L. acidophilus and M. luteus, Streptococcus pneumoniae and Bacillus cereus were $13.73 \pm 0.22,10.63 \pm 0.25,11.16 \pm 0.21 ; 12.3 \pm 0.19$, $14.23 \pm 0.21,9.80 \pm 0.18 ; 13.8 \pm 0.12,16.43 \pm 0.28,9.86 \pm 0.17$; respectively (Table 2). Triton X-100 (0.1\%) proved to be a good solubilizing agent for toxin/proteins. Higher protein solubilization was observed in the supernatant than in the residue, except TCA (Figure 1). Spider toxins show haemolytic and and insecticidal in nature [22]. Because of their strong cytolytic and cytotoxic activity [23], Juruin isolated from the venom of the Amazonian Pink Toe spider, Avicularia juruensis, shows antifungal activity [24], while cupiennin 1a isolated from neotropical wandering spider Cupiennius salei exhibits remarkably broad, spectrum activity against bacteria [25], protozoan parasites, insects, and shows cytolytic action against human cancer cells [26]. Similar antimicrobial potential was seen in LyeTx I, [27] latarcin [28] and synthetic analogues of peptides from the venom of the Central Asian spider Lachesana tarabaevi [22]. Here it can be concluded that spider toxins are potential antimicrobial agents and display broad spectrum activity due to their complex structure. These can be used as antimicrobial therapeutic agent and can easily replace highly toxic drugs which put adverse effect on patients after their administration [26] [29].

\section{References}

[1] Coddington, J.A. and Levi, H.W. (1991) Systematics and Evolution of spider (Araneae). Annual Review of Ecology and Systematics, 22, 565-592. http://dx.doi.org/10.1146/annurev.es.22.110191.003025

[2] Luo, J., Zhang, Y., Gong, M., Lu, S., Ma, Y., Zeng, X. and Liang, S. (2014) Molecular Surface of JZTX-V ( $\beta$-Theraphotoxin-Cj2a) Interacting with Voltage-Gated Sodium Channel Subtype NaV1.4. Toxins (Basel), 6, 2177-2193. http://dx.doi.org/10.3390/toxins6072177

[3] Anand, P., Grigoryan, A., Bhuiyan, M.H., Ueberheide, B., Russell, V., Quinoñez, J., Moy, P., Chait, B.T., Poget, S.F. and Holford, M. (2014) Sample Limited Characterization of a Novel Disulfide-Rich Venom Peptide Toxin from Terebrid Marine Snail Terebra variegata. PLoS One, 9, e94122. http://dx.doi.org/10.1371/journal.pone.0094122

[4] Sapag, A., Salinas-Luypaert, C. and Constenla-Monoz, C. (2014) First Report of the Vitro Selection of the RNA Aptamers Targated to Recombinant Loxosceles Laeta Spider Toxins. Biological Research, 47, 0717-6287.

[5] Liu, H., Yu, H., Yan, Y., Duan, Z. and Wang, X. (2014) Detection and Identification of Huwentoxin-IV Interacting Proteins by Biotin-Avidin Chemistry Combined with Mass Spectrometry. Journal of Venomous Animals and Toxins including Tropical Diseases, 20, 18.

[6] Ahmed, A. and Beg, A.Z. (2001) Antimicrobial and Phytochemical Studies on 45 Indian Medicinal Plants against Multi-Drug Resistant Human Pathogens. Journal of Ethopharmocology, 74, 113-123. http://dx.doi.org/10.1016/S0378-8741(00)00335-4

[7] Hu, Z., Zhou, X., Chen, J., Tang, C., Xiao, Z., Ying, D., Liu, Z. and Liang, S. (2014) The Venom of the Spider Selenocosmia jiafu Contains Various Neurotoxins Acting on Voltage-Gated Ion Channels in Rat Dorsal Root Ganglion 
neurons. Toxins (Basel), 6, 988-1001. http://dx.doi.org/10.3390/toxins6030988

[8] Lowry, O.H., Rosenbrough, N.J., Farr, A.L. and Randall, R.J. (1951) Protein Measurement with Phenol Reagent. The Journal of Biological Chemistry, 193, 265-275.

[9] Spier, R.E. (1982) Gel Filtration Column: Animal Cell Technology: An Overview. Journal of Chemical Technology and Biotechnology, 32, 304-312. http://dx.doi.org/10.1002/jctb.5030320134

[10] NCCLS (National Committee for Clinical Laboratory Standards) (1993) Performance Standard for Antimicrobial Disc Susceptibility Tests. Approved Standard. National Committee for Clinical Laboratory Standards, Villanova, P.A. Publication M2-A5. USA.

[11] Amsterdam, D. (1996) Susceptibility Testing of Antimicrobials in Liquid Medium. In: Baltimore, L.V., Williams, M.D. and Wilikins, Eds., Antibiotics in Laboratoratory Medicine, 4th Edition, 52-111.

[12] Wang, X., Yu, H., Liu, H., Yan, Y. and Duan, Z. (2014) Detection and Identification of Huwentoxin-IV Interacting Proteins by Biotin-Avidin Chemistry Combined with Mass Spectrometry. Journal of Venomous Animals and Toxins including Tropical Diseases, 20, 18.

[13] Dubovskii, P.V., Vassilevski, A.A., Kozlov, S.A., Feofanov, A.V., Grishin, E.V. and Efremov, R.G. (2015) Latarcins: Versatile Spider Venom Peptides. Cellular and Molecular Life Sciences, 72, 4501-4522. http://dx.doi.org/10.1007/s00018-015-2016-X

[14] Lei, Q., Yu, H., Peng, X., Yan, S., Wang, J., Yan, Y. and Wang, X. (2015) Isolation and Preliminary Characterization of Proteinaceous Toxins with Insecticidal and Antibacterial Activities from Black Widow Spider (L. tredecimguttatus) Eggs. Toxins (Basel), 16, 886-899.

[15] Kuznetsov, A.S., Dubovskii, P.V., Vorontsova, O.V., Feofanov, A.V. and Efremov, R.G. (2014) Interaction of Linear Cationic Peptides with Phospholipid Membranes and Polymers of Sialic Acid. Biochemistry (Mosc), 79, 459-468. http://dx.doi.org/10.1134/S0006297914050101

[16] Johnson, E.T., Dowd, P.F. and Hughes, S.R. (2014) Expression of a Wolf Spider Toxin in Tobacco Inhibits the Growth of Microbes and Insects. Biotechnology Letters, 36, 1735-1742. http://dx.doi.org/10.1007/s10529-014-1536-z

[17] Tan, H., Ding, X., Meng, S., Liu, C., Wang, H., Xia. L., Liu, Z. and Liang, S. (2013) Antimicrobial Potential of Lycosin-I, a Cationic and Amphiphilic Peptide from the Venom of the Spider Lycosa singorensis. Current Molecular Medicine, 13, 900-910. http://dx.doi.org/10.2174/15665240113139990045

[18] Chen, R. and Chung, S.H. (2013) Effect of Gating Modifier Toxins on Membrane Thickness: Implications for Toxin Effect on Gramicidin and Mechanosensitive Channels. Toxins (Basel), 5, 456-471.

[19] Garcia, F., Villegas, E., Espino-Solis, G.P., Rodriguez, A., Paniagua-Solis, J.F., Sandoval-Lopez, G., Possani, L.D. and Corzo, G. (2013) Antimicrobial Peptides from Arachnid Venoms and Their Microbicidal Activity in the Presence of Commercial Antibiotics. The Journal of Antibiotics (Tokyo), 66, 3-10. http://dx.doi.org/10.1038/ja.2012.87

[20] Idiong, G., Won, A., Ruscito, A., Leung, B.O., Hitchcock, A.P. and Ianoul, A. (2011) Investigating the Effect of a Single Glycine to Alanine Substitution on Interactions of Antimicrobial Peptide Latarcin 2a with a Lipid Membrane. European Biophysics Journal, 40, 1087-1100. http://dx.doi.org/10.1007/s00249-011-0726-z

[21] Won, A., Khan, M., Gustin, S., Akpawu, A., Seebun, D., Avis, T.J. and Hitchcock, A.P. (2011) Investigating the Effects of L- to D-Amino Acid Substitution and Deamidation on the Activity and Membrane Interactions of Antimicrobial Peptide Anoplin. Biochimica et Biophysica Acta (BBA)—Biomembranes, 1808, 1592-1600. http://dx.doi.org/10.1016/j.bbamem.2010.11.010

[22] Vassilevski, A.A., Kozlov, S.A., Samsonova, O.V., Egorova, N.S., Karpunin, D.V., Pluzhnikov, K.A., Feofanov, A.V. and Grishin, E.V. (2008) Cyto-Insectotoxins, a Novel Class of Cytolytic and Insecticidal Peptides from Spider Venom. Biochemical Journal, 411, 687-696. http://dx.doi.org/10.1042/BJ20071123

[23] Vorontsova, O.V., Egorova, N.S., Arseniev, A.S. and Feofanov, A.V. (2011) Haemolytic and Cytotoxic Action of Latarcin Ltc2a. Biochimie, 93, 227-241. http://dx.doi.org/10.1016/j.biochi.2010.09.016

[24] Ayroza, G., Ferreira, I.L., Sayegh, R.S., Tashima, A.K. and da Silva Junior, P.I. (2012) Juruin: An Antifungal Peptide from the Venom of the Amazonian Pink Toe Spider, Avicularia juruensis, which Contains the Inhibitory Cystine Knot Motif. Frontiers in Microbiology, 3, Article 324. http://dx.doi.org/10.3389/fmicb.2012.00324

[25] Pukala, T.L., Doyle, J.R., Llewellyn, L.E., Kuhn-Nentwig, L., Apponyi, M.A., Separovic, F. and Bowie, J.H. (2007) Cupiennin 1a, an Antimicrobial Peptide from the Venom of the Neotropical Wandering Spider Cupiennius salei, Also Inhibits the Formation of Nitric Oxide by Neuronal Nitric Oxide Synthase. The FEBS Journal, 274, 1778-1784. http://dx.doi.org/10.1111/j.1742-4658.2007.05726.x

[26] Kuhn-Nentwig, L., Willems, J., Seebeck, T., Shalaby, T., Kaiser, M. and Nentwig, W. (2011) Cupiennin 1a Exhibits a Remarkably Broad, Non-Stereospecific Cytolytic Activity on Bacteria, Protozoan Parasites, Insects, and Human Cancer cells. Amino Acids, 40, 69-76. http://dx.doi.org/10.1007/s00726-009-0471-0

[27] Santos, D.M., Verly, R.M., Piló-Veloso, D., de Maria, M., de Carvalho, M.A., Cisalpino, P.S. and Soares, B.M. (2010) 
LyeTx I, a Potent Antimicrobial Peptide from the Venom of the Spider Lycosa erythrognatha. Amino Acids, 39, 135144. http://dx.doi.org/10.1007/s00726-009-0385-X

[28] Shlyapnikov, Y.M., Andreev, Y.A., Kozlov, S.A., Vassilevski, A.A. and Grishin, E.V. (2008) Bacterial Production of Latarcin 2a, a Potent Antimicrobial Peptide from Spider Venom. Protein Expression and Purification, 60, 89-95. http://dx.doi.org/10.1016/j.pep.2008.03.011

[29] Ali, M.P., Yoshimatsu, K., Suzuki, T., Kato, T. and Park, E.Y. (2014) Expression and Purification of Cyto-Insectotoxin (Cit1a) Using Silkworm Larvae Targeting for an Antimicrobial Therapeutic Agent. Applied Microbiology and Biotechnology, 98, 6973-6982. http://dx.doi.org/10.1007/s00253-014-5728-1

\section{Submit or recommend next manuscript to SCIRP and we will provide best service for you:}

Accepting pre-submission inquiries through Email, Facebook, LinkedIn, Twitter, etc.

A wide selection of journals (inclusive of 9 subjects, more than 200 journals)

Providing 24-hour high-quality service

User-friendly online submission system

Fair and swift peer-review system

Efficient typesetting and proofreading procedure

Display of the result of downloads and visits, as well as the number of cited articles

Maximum dissemination of your research work

Submit your manuscript at: http://papersubmission.scirp.org/ 